\title{
Transition and Transgression of Identity in Chuck Palahniuk's Survivor
}

\author{
Drd. Ali Mohammed Hasan \\ University of Craiova, Romania
}

\begin{abstract}
The post-modernist concerning with identity and subjectivity posits that identity is multi-faceted and constantly gets re-constructed by choice. This results in increasingly fragmented and unstable identities leading to an inevitable breakdown in social relationships and sanity. A limited and dependable set of coherent identities began to fragment into a diverse and unstable series of competing identities. Post-modernism stifled the idea of nation, religion, family, and identity as bedrocks of stability and security. Disillusioned post-modernist world has deconstructed the well-defined boundaries that governed the life, otherwise, transition and transgression through and across these domains became the norm that allowed negotiation in daily lives. Where the subject became a terminal of multiple networks, consciously enacting the repetitions through which identity was getting produced and changed, demonstrating identity's "performativity". Establishing that what we believe to be true is only a construction or an interpretation of reality, shaped by our own socially constructed bias, thereby putting to scrutiny the idea of reality and real itself, which removed any sense of objective reality and with it the notion of an objective self. Identity is constantly changing and transitioning, the idea of the self which is entangled with multiplicity, heterogeneity, difference and ceaselessly becoming caught between the present and future, real and unreal, death and life. This research paper will carry out an analysis on evidential aspects in the selected novel and will further interpret the episodes of transition and transgressions that inform this novel.
\end{abstract}

Keywords: transgression, subjectivity, identity, transition, Chuck Palahniuk

\section{Introduction}

In the domain of the social sciences lately, the ideas of identity and character continue to be located at the center of the debate around the idea of transition and transgression. Interdisciplinary science that transgresses and synthesizes the other set doctrines and methodologies of any discipline adopts an eclectic method and postmodern trend, having a transformative and transitioning effect on the self-concept and identity debate. The post-modernist concerning with identity and subjectivity posits that identity is multi-faceted and constantly gets re-constructed by choice (Delfino, 2007). This results in increasingly fragmented and unstable identities leading to an inevitable breakdown in social relationships and sanity. Consequently, a limited and dependable set of coherent identities began to fragment into a diverse and unstable series of competing identities. Apart from identity, Post-modernism stifled the idea of nation, religion, family, and identity as bedrocks of stability and security. Disillusioned post-modernist world has deconstructed the well-defined boundaries that governed the life, otherwise, transition and transgression through and across these domains became the norm that allowed

Drd. Ali Mohammed Hasan, assistant lecturer, master, Department of English, Shatt Al-Arab Univeristy College, Basra, Iraq. 
negotiation in daily lives (Muller, 2006). Where the subject became a terminal of multiple networks, consciously enacting the repetitions through which identity was getting produced and changed, demonstrating identity's "performativity" (Lagerspetz, 2009). Establishing the idea that what we believe to be true is only a construction or an interpretation of reality, shaped by our own socially constructed bias, thereby putting to scrutiny the idea of reality and real itself. This removed any sense of objective reality and with it the notion of an objective self. This further posited that not only identity but the concepts of reality and the paradigms that governed life and identity are constantly changing and transitioning, the idea of the self which is entangled with multiplicity, heterogeneity, difference and ceaselessly becoming caught between the present and future, real and unreal, death and life (Barthes, 1977). Even after a lot of theorization and understanding of the definition of post-postmodernism, it is still being constructed and is hazy at best, as critics from various fields attempt to define it or writers/authors try to incorporate it into their works, since it is in the midst of the movement (McNally, 2012). A working definition that the critics agree on focuses on informed naivety, pragmatic idealism, and moderate fanaticism of the various cultural responses. This research paper intends to carry out an analysis on evidential aspects of post-modern anxiety of identity in the selected novel and will further interpret the episodes of transition and transgressions that inform this novel.

\section{Convergence of Transgression and Transition}

Palahniuk describes his own work as "transgressional fiction". Transgressive fiction is not (always) transgressive in itself, but reflects the transgressive dynamics which occur in its socio-historical context. Because it reflects and exaggerates potentially disturbing extra-textual phenomena, transgressive fiction can indeed be disturbing in nature, but by exposing transgressive social mechanisms, it also allows for the critical dissection (Booker, 1991). Transgressional fiction can be defined as the crossing of multiple genres in a work that creates a seemingly new genre, or one that has not yet been explored. This places Palahniuk's work in the domain of transitional space which, by definition, epitomizes the uncertainty of an existence caught in-between two conditions, stages of development and worlds. A transitional space as defined by William Bridges (1991) is "a neutral zone" which refers to "an in-between time when the old is gone but the new isn't fully operational" (p. 3). Particularly, Palahniuk's novel, Survivor (1999), is set in just such a transitional world wherein the postmodern anxiety of transgression and transition of identity of the individual/protagonist abounds the novel. It prefigures the changing status of transgressive fiction as the decade reached its conclusion. The novel follows the story of the protagonist, Tender Branson who is, or rather, was a member of the Creedish Church member or a member of a doomsday cult, who decides to hijack a plane in order to escape from the US, where he has become a mainstream religious icon (Truffin, 2009). The pages of Survivor are numbered in reverse order, enforcing the urgency of Tender's monologue as he searches for a way to escape from the plane and the social system in which he has become imprisoned. The novel ends in midsentence, leaving it up to the reader to decide whether Tender dies or survives. It is a raw critique on the nature of fame in America and the larger idea of American dream itself. In a blatant and explicit manner, the story exhibits Tender's transformation from a nobody to a religious celebrity and the illusions behind it all.

Tender comments on the process of his transformation:

The agent's yelling that no matter how great you look, your body is just something you wear to accept your Academy Award. 
Your hand is just so you can hold your Nobel Prize.

Your lips are only there for you to air-kiss a talk show host.

And you might as well look great.

It's around the one hundred and twentieth floor you have to laugh. You're going to lose it anyway. Your body. You're already losing it. It's time you bet everything.

This is why when the agent comes to you with anabolic steroids, you say yes. You say yes to the back-to-back tanning sessions. Electrolysis? Yes. Teeth capping? Yes. Dermabrasion? Yes. Chemical peels? According to the agent, the secret to getting famous is you just keep saying yes. (Palahniuk, 1999, pp. 150-149)

Survivor exhibits that transgression means adaption to a changing social environment. Contemporary space is dominated by new technological and electronic devices that turn the traditional time and space continuum. Palahniuk's real skill comes out in his portrayal of this contemporary transitional world in this novel and in his ability to pack subtext into every little phrase and loop. Rattling about beneath the surface are themes of transitioning parameters of narrative, religion, free will, reality, and false security (Sondergard, 2009). The narrative unfolds in hindsight along with chunks of interruptions from the current scenario, the narrator piles up details one after another, the loops and repetitions accumulate, and gradually the reader is admitted into the mind of Tender Branson, which feels like domain in transition between the real and the hyper-real world. Not only the transition between the real and the hyper real, the novel also elaborates on the transition between sanity and insanity. As Lars Bernaerts (2015) pointed out to the reader that the use of structural elements of post-postmodernism in reading Palahniuk's texts places it in the genre of transition and transgression, in the case of Survivor, the use of delirium in the narrative particularly. According to Bernaerts (2015), "elements that enable us to identify the delirium are an important manifestation of madness that is anchored in the narrative: an alternative relation to reality, an alternative coherence, a strong belief, a psychological motivation, and a pathological background" (p. 376). While each reading of Palahniuk's work offers a vastly different interpretation of the text, each agrees that his work offers a haunting insight into 21 st century American life of the bourgeoisie. Survivor maintains the metaphor of violent secret lives beneath the bourgeoisie exteriors of people.

In the ways they "get blood stains out of a fur coat" or "get blood off piano keys" (Palahniuk, 1999, p. 269), to hide bullet holes in the living room wall (Palahniuk, 1999, p. 268) or repair stab holes in night gowns and tuxedoes, and hats. (Palahniuk, 1999, p. 269)

The demands on the individual, the grotesque nature of the present, and the absurdity of American society's expectations in Palahniuk's novel, with its take on modern capitalist and religious alienation, shot through our media-saturated world, appealed to a brain that was feeling similarly alienated by modern society. That is, a world that fails over and over again to deliver its promises of liberation and transcendence, whether through spirituality or whatever material possessions and peace of mind money cannot buy the grand idea of The American Dream (Mendita, 2005).

\section{Transgressing the Social as Well as the Personal}

The idea of transgression and transition of identity in the novel is also exemplified by the transitioning notions of gender, particularly through the protagonist Tender Branson who experiences a personal paradigm 
shift in his own behaviour from a state of emasculation to a false sense of masculinity. This shift occurs because the reader experiences the main characters changing the way they behave from traditionally feminine behaviours of subservience and sensitivity to the more traditionally masculine behaviour displaying dominance and role of the provider. Survivor represents the ultimate social effects that choosing to not deal with such emasculation can cause (Ash, 2009). Through this novel, Palahniuk exposes the problem of gender essentialist thought and showcases the need for a society that recognizes the fluidity of gender identity. Survivor almost creates a code of conduct that men ought to follow for the sanctity of the individual and enlightenment of society as a whole.

Tender Branson is shown as an effeminate character who the reader can only feel sympathetic for. The tension created by the emasculated Tender engages the reader awkwardly. Palahniuk forces the reader into an uncomfortable position by placing Tender in the opposite gender stereotype than the one that the Male readers typically would want to identify with. Because of society's determination of what a man "ought" to look like, Tender is transformed to fit that ideal and the acts he can perform in order to escape the demands of his Agent who is limited to extreme acts of violence. Towards the end of Survivor, there is an exchange between Tender and his brother Adam:

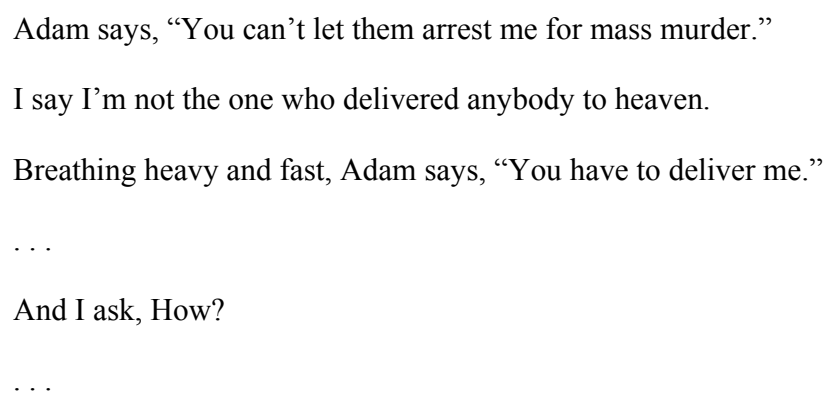

With his other hand, Adam grabs at the ground beside him and drags an open magazine across his mutilated face. The magazine shows a man and a woman copulating, and from under it Adam says, "When you find a rock. Bring it down on my face when I tell you”. (Palahniuk, 1991, pp. 30-31)

This incident exemplifies an experience of extreme violence because the performative act of violence is typically associated with the masculine identity and that is how Tender has performed, aligning with the stereotypical behaviours of the masculine (Buchbinder, 2013).

\section{Tender Branson as the Embodiment of Transgression and Transition}

Tender Branson, the protagonist of the novel Survivor, quickly rises to stardom, creating a nationwide following. His agreement with the demands of his agent stems from his desire of wanting an enormous audience to witness his suicide. From the start of the novel, the reader understands that Tender has no real desire to live. He hosts a local suicide hotline, revelling in the divine power he is able to hold over those that call. Tender was raised under the impression that when the time came, he must have committed suicide for his church (Boon, 2003). When the other members of the Creedish Family commit mass suicide and the remaining members of the Creedish in the outside world begin to die, this weighs heavy on him; should he kill himself like he was taught to do, or should he take this opportunity to live and grow? There are no ties to keep him alive, save for Fertility Hollis. Fertility challenges Tender as she is the one person who holds a greater level of divine wisdom than him; she can actually foresee the future while Tender can only nudge those already close to the 
edge. There is a level of bewilderment as he becomes aware of the influence and power he is capable of after his agent transforms him. The epiphany comes while on his Stairmaster: the tool of which sculpts and strengthens his body while wearing away at his sanity, Tender narrates:

As if people know anything about being a celebrated famous celebrity spiritual leader. As if any one of those people isn't already looking around for a new guru to make sense out of their risk-free boredom of a lifestyle while they watch the news on television and pass judgment on me. People are all looking for that, a hand to hold. Reassurance. The promise that everything will be all right. That's all they wanted from me. Stressed, desperate, celebrated me. Under-pressure me. None of these people know the first thing about being a big, glamorous, big, charismatic, big role model.

It's stair climbing around floor number one hundred and thirty you start raving, ranting, speaking in tongues. (Palahniuk, 1999, p. 138)

Tender is a religious celebrity and hopes to use this devout, momentary congregation for his own good. It is his selfish actions that Palahniuk scrutinizes. Tender has the ability to influence a large number of people yet he chooses to be passive about this opportunity, yet he has failed to speak to those who may need true guidance, not just another short prayer book or a television spot that reminds them to be a somewhat decent being (Tuss, 2004). Tender's ambivalent form of existence directly contrasts the method by which men are typically thought to behave and men are expected to normatively be decisive and action-oriented. The reader's experience with Tender is one of frustration. Where Tender is presented with an amazing opportunity to reach the masses, he only passively engages with them; instead, Tender focuses on Fertility and selfish hopes of creating a relationship with her. Tender and his Agent take advantage of those that have flocked towards him, looking only for a profit. This affirms the stereotypical notion that men only look out for their own interest. What we see in Survivor is the embodiment of normative male behaviour creating a self-sustaining cyclical rotation of celebrity that is artificial in every sense of the word and can only assume to be egocentric and narcissistic (Burgess, 2012).

With the thrust into the world of Contemporary America, he encounters the rampant commercialism that exists and he realizes that no matter how many luxuries you get, something will be always missing. No matter how carefully you choose, you will never be "totally happy" (Palahniuk, 1999, p. 60). Tender is only able to begin reaching towards the satisfaction of his true needs once he has experienced an act of genuine communion with another human being, in this case having sex with Fertility Hollis, but eventually this leads to his death instead. Towards the end of the novel, the narrator says:

It's all done. It's all just a story now.

Here's the life and death of Tender Branson, and I can just walk away from it. (Palahniuk, 1999, p. 1)

This exemplifies the transgression of the narrative authority and this narrative uncertainty shows moral uncertainty too which is existent not only in Tender Branson, but he is a mere metaphor for American men in the larger context who are negotiating their daily lives in this uncertain domain of Transgression and Transition.

\section{Conclusion}

This paper offers various approaches of how to study transgression and transition and aims to dissect and bisect these phenomena in a deep manner by analysing Chuck Palahniuk's novel, Survivor. Transgression and transition are multifaceted and complex and get expressed explicitly through the themes of identity, religion, 
violence, non-linear narrative devices, minimalism, and repetition in the novel Survivor. This text is particularly placed in the post-modern domain which adds more complexity and intricacy to the phenomenon of transgression and transition, which gets embodied and exemplified in the post-modern anxiety. Palahniuk's methods of writing reflect on the protagonist, Tender Branson's increasingly fractured state of mind, morals, actions, drives, and ideas. He is the one who undergoes transition willingly or unwillingly because of external forces. In other words, he undergoes transition in social sphere when he becomes the most prominent member of a cult from being a mere servant, along with it he continues to transgress from the actual lineaments of his personal identity; from being a religious fanatic he becomes a person hankering after sex. $\mathrm{He}$ is the post-modern man around whom the bedrocks of stability and security have been dismantled and deconstructed, and he is consequently forever stuck in the phase of transition.

\section{References}

Ash, S. (2009). Going to the body: The tension of freedom/restraint in Palahniuk's novels. In Sacred and immoral: On the writings of Chuck Palahniuk. Newcastle upon Tyne: Cambridge Scholars Pub.

Barthes, R. (1977). The death of the author. In R. Barthes, Image, music, text (pp. 142-148). London: Fontana Press.

Booker, M. K. (1991). Techniques of subversion in modern literature: Transgression, abjection and the carnivalesque. Gainesville: U of Florida P.

Boon, K. A. (2003). Men and nostalgia for violence: Culture and culpability in Chuck Palahniuk's Survivour. Journal of Men's Studies, 11(3), 267-276.

Bridges, W. (1991). Managing transitions: Making the most of change. UK: W. S. Bookwell.

Buchbinder, D. (2013). Studying men and masculinities. Abingdon: Routledge.

Burgess, O. (2012). Revolutionary bodies in Chuck Palahniuk's Fight Club. Utopian Studies: Journal of the Society for Utopian Studies, 23(1), 263-280.

Delfino, A. S. (2007). Becoming the new man in post-postmodernist fiction: Portrayals of masculinities in David Foster Wallace's Infinite Jest and Chuck Palahniuk's Fight Club. Saabruchen, Germany: VDM Verlag Dr. Muller.

Lagerspetz, S. (2009). Striving for the impossible: The Hegelian background of Judith Butler (Unpublished master's thesis, $\begin{array}{lllllll}\text { University of } & \text { Helsinki). } & \text { Retrieved } & 14 & \text { March, } & 2018 & \text { from }\end{array}$ https://helda.helsinki.fi/bitstream/handle/10138/21787/striving.pdf?sequence=2

McNally, D. (2012). Monsters of the market: Zombies, vampires and global capitalism. London: Haymarket.

Mendieta, E. (2005). Surviving American culture: On Chuck Palahniuk. Philosophy \& Literature, 29(2), 394-408.

Muller, M. (2006). Discourses of postmodern epistemology: Radical impetus lost? Progress in Development Studies, 6(4), 306-320.

Palahniuk, C. (1999). Survivor. New York: W. W. Norton \& Company.

Sondergard, S. L. (2009). Chuck Palahniuk and the semiotics of personal doom: The novelist as escape artist. In Reading Chuck Palahniuk: American monsters and literary mayhem. New York: Routledge.

Truffin, S. R. (2009). This is what passes for free will: Chuck Palahniuk's postmodern gothic. In Reading Chuck Palahniuk: American monsters and literary mayhem. New York: Routledge.

Tuss, A. (2004). Masculine identity and success: A critical analysis of Patricia Highsmith's talented Mr Ripley and Chuck Palahniuk's Survivor. Journal of Men's Studies, 12(2), 93-102. 